\title{
Production of Human Beta Interferon in Insect Cells Infected with a Baculovirus Expression Vector
}

\author{
GALE E. SMITH, MAX D. SUMMERS,* AND M. J. FRASER \\ Department of Entomology, Texas A\&M University, and Texas Agricultural Experiment Station, College \\ Station, Texas 77843
}

Received 16 May 1983/Accepted 23 September 1983

\begin{abstract}
Autographa californica nuclear polyhedrosis virus (AcNPV) was used as an expression vector for human beta interferon. By using specially constructed plasmids, the protein-coding sequences for interferon were linked to the AcNPV promoter for the gene encoding for polyhedrin, the major occlusion protein. The interferon gene was inserted at various locations relative to the AcNPV polyhedrin transcriptional and translational signals, and the interferon-polyhedrin hybrid genes were transferred to infectious AcNPV expression vectors. Biologically active interferon was produced, and greater than $95 \%$ was secreted from infected insect cells. A maximum of ca. $5 \times 10^{6} \mathrm{U}$ of interferon activity was produced by $10^{6}$ infected cells. These results demonstrate that AcNPV should be suitable for use as a eucaryotic expression vector for the production of products from cloned genes.
\end{abstract}

Autographa californica nuclear polyhedrosis virus (AcNPV) has a genome of ca. 130 kilobases of double-stranded, circular DNA and is the most extensively studied baculovirus (for recent reviews see references 13 and 20). Its host range is limited to lepidoptera species and cultured lepidoptera cells, and it is currently being considered for agricultural use as a viral insecticide. AcNPV has a biphasic replication cycle and produces a different form of infectious virus during each phase. Between 10 and $24 \mathrm{~h}$ postinfection (p.i.), extracellular virus is produced by the budding of nucleocapsids through the cytoplasmic membrane. By 15 to $18 \mathrm{~h}$ p.i., nucleocapsids are enveloped within the nucleus and viral occlusions begin to form. Each occlusion contains many virus particles embedded in a paracrystalline protein matrix, which is formed from a single major protein called polyhedrin. In infected Spodoptera frugiperda (fall armyworm, Lepidoptera, Noctuidae) cells, AcNPV polyhedrin accumulates to high levels and constitutes $25 \%$ or more of the total protein mass in the cell (34); it is probably synthesized in greater abundance than any other protein in a virus-infected eucaryotic cell.

Polyhedrin is encoded by the virus (40), and the gene has been mapped (34) and sequenced (B. J. L. Hooft van Iddekinge, G. E. Smith, and M. D. Summers, Virology, in press). From an analysis of viral deletion mutants, we demonstrated that the polyhedrin gene is not required for the production of infectious extracellular virus (30). Inactivation of the polyhedrin gene by deletion (30) or, as will be demonstrated in this report, by insertion results in mutants that do not produce occlusions in infected cells. These occlusion-negative viruses form plaques that are different from plaques produced by wild-type viruses, and this distinctive plaque morphology is used as a means to screen for recombinant viruses (30).

Several properties of AcNPV that may make this virus ideally suited as an expression vector for cloned eucaryotic genes have been described (20). These include the potential of the rodshaped virus to encapsidate viral genomes with large pieces of additional, foreign DNA and the inherent safety of a recombinant viral vector that is not pathogenic to vertebrates. In addition, the polyhedrin gene provides: (i) a nonessential region of the AcNPV genome in which to insert foreign DNA, (ii) a very strong promoter which directs transcription late in infection after extracellular virus is produced and after host genes and most viral genes are turned off, and (iii) a genetic marker to select for recombinant viruses. To examine the utility of AcNPV as an expression vector, we fused the gene for human beta interferon (IFN- $\beta$ ) to the AcNPV polyhedrin promoter and measured its production in infected cells.

IFN- $\beta$ is known to have antiviral, antiproliferative, and antitumor properties and should prove important in a variety of medical applications. Although cultured human cells normally do not produce interferon, treatment with inducers such as viruses or double-stranded RNA 
results in a transient and relatively low-level biosynthesis of IFN- $\beta$ (35). The IFN- $\beta$ gene has been expressed in Escherichia coli cells by fusing interferon protein-coding sequences to bacterial promoter and ribosomal binding sites in plasmid $(8,37)$ or lambda phage $(22)$ vectors. Nonhuman mammalian cells have also been employed to synthesize IFN $-\beta$ from the cloned gene. For example, the IFN- $\beta$ gene has been cloned with its protein-coding sequences under the transcriptional control of a simian virus $\mathbf{4 0}$ promoter (7), a herpes simplex virus thymidine kinase promoter (25), or its own genetic signals $(2,11,21,24,43)$. The highest reported levels of beta interferon activity produced in bacterial and animal host-vector systems are $1 \times 10^{4} \mathrm{U} / \mathrm{ml}$ in $E$. coli cells $(8)$ and $5 \times 10^{4} \mathrm{U} / \mathrm{ml}$ in transformed mouse cells (11). By using AcNPV as an expression vector, biologically active IFN- $\beta$ was efficiently secreted in the media of infected cells and reached a titer of $5 \times 10^{6} \mathrm{U} / \mathrm{ml}$. In addition, the IFN- $\beta$ protein was glycosylated, and our data indicate that the signal peptide at the amino-terminal end of the primary translation product was removed.

\section{MATERIALS AND METHODS}

Cells and virus. AcNPV stocks were grown and titers were determined in $S$. frugiperda cells (IPLBSF21-AE), using Hink medium (12) plus $10 \%$ fetal bovine serum (FBS) as described previously (31).

Human amnionic (WISH) cells were maintained in Earle minimum essential medium supplemented with penicillin $(100 \mathrm{U} / \mathrm{ml})$, mycostatin $(50 \mathrm{U} / \mathrm{ml})$, and $15 \%$ FBS.

Interferon. Interferon activity was determined by the virus plaque-reduction assay (18) in WISH cells challenged with vesicular stomatitis virus. Serial dilutions $(0.5 \mathrm{log})$ of culture media from recombinant AcNPV-infected cells were made over $2.5 \times 10^{4}$ WISH cells in 96-well microtiter plates. After $12 \mathrm{~h}$ at $37^{\circ} \mathrm{C}$, each well was infected with ca. $60 \mathrm{PFU}$ of vesicular stomatitis virus, and the cells were overlaid with $0.5 \%$ methyl cellulose in Earle minimum essential medium. At $24 \mathrm{~h}$ p.i., the cell monolayers were stained with crystal violet and the plaques were counted. An international reference standard of human interferon was included in all assays, and the activity was expressed in National Institutes of Health reference units (IU) per milliliter.

Transfection and selection for recombinant viruses. The procedure used to transfect $S$. frugiperda cells and the marker-transfer method used to select for recombinant AcNPV expression vectors were as described previously (30).

Protein blot radioimmunoassay. Total cellular proteins were electrophoretically separated and then reacted with antibody as described previously (32). At 30 h p.i., cells were washed with $1 \times$ phosphate-buffered

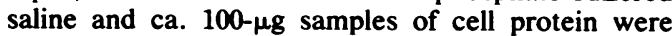
electrophoresed on a sodium dodecyl sulfate-12\% polyacrylamide gel (12) and then transferred by diffusion to two nitrocellulose filters. The filters were incubated with either a 1:1,000 dilution of rabbit antiserum prepared against AcNPV polyhedrin (32) or a $10-\mu \mathrm{g} / \mathrm{ml}$ concentration of monoclonal antibody to recombinant IFN- $\beta$ (Hoffmann-La Roche Inc., Nutley, N.J.). Specifically bound antibody was detected by using radioiodinated Staphylococcus aureus protein $\mathbf{A}$.

Radiolabeling of infected cells and analysis of polypeptides. At various times after infection, cells were labeled for $30 \mathrm{~min}$ in leucine-free Grace medium (9) supplemented with $2 \%$ dialyzed FBS and $\mathrm{L}-\left[^{3} \mathrm{H}\right] \mathrm{leu}-$ cine at $100 \mu \mathrm{Ci} / \mathrm{ml}$ or for $\mathbf{6 0 ~ m i n ~ i n ~ G r a c e ~ m e d i u m ~ w i t h ~}$ $10 \%$ the normal glucose supplemented with $2 \%$ dialyzed FBS and D-[2- $\left.{ }^{3} \mathrm{H}\right]$ mannose at $200 \mu \mathrm{Ci} / \mathrm{ml}$. To label cells in the presence of tunicamycin, infected cells were pretreated for 20 to $30 \mathrm{~h}$ p.i. with $5 \mu \mathrm{g}$ of tunicamycin per $\mathrm{ml}$ and then labeled as described above with $\left.L-{ }^{3} \mathrm{H}\right]$ leucine in the presence of $5 \mu \mathrm{g}$ of tunicamycin per $\mathrm{ml}$. The labeled cells were washed with Grace medium, disrupted and electrophoresed on sodium dodecyl sulfate- $12 \%$ polyacrylamide gels, and then processed for fluorography as described previously (33). Molecular weights were calculated by comparing electrophoretic mobility with that of protein markers (Pharmacia Fine Chemicals, Piscataway, N.J.).

Construction of AcNPV transfer vectors. AcNPV EcoRI-I, which contains the polyhedrin gene $(1,26$, 33), was cloned into the EcoRI site of pUC8 (41). The resulting plasmid (pI8) has three BamHI recognition sites: one in the polyhedrin gene, one in EcoRI-I downstream from the polyhedrin gene, and one in the cloning region of pUC8. The BamHI site in pUC8 was removed by digesting pI8 successively with PstI, $S m a I$, and S1 nuclease. E. coli JM83 cells were transformed with the digested DNA, and a plasmid was isolated that was missing PstI, BamHI, SmaI, and EcoRI restriction sites in the cloning region of pUC8. This plasmid was partially digested with BamHI, and full-length linear DNA was isolated from an agarose gel, treated with $\mathrm{S} 1$ nuclease $(500 \mathrm{U} / \mathrm{ml})$ at $37^{\circ} \mathrm{C}$ for 15 min, circularized with T4 DNA ligase, and used to transform JM83 cells. A plasmid (pAc101) was identified with a single BamHI site located ca. 220 bases from the polyhedrin transcriptional start site (Fig. 1; 34).

The following procedure was used to modify pAc101 such that some or all of the DNA sequences between the transcriptional start site and the BamHI recognition sequence in the polyhedrin gene were deleted and replaced by a synthetic BamHI linker sequence, 5'dCGGATCCG-3' (P-L Biochemicals, Inc., Milwaukee, Wis.). The EcoRI-to-BamHI fragment in AcNPV EcoRI-I (located 0 to 4,210 bases in EcoRI-I; see reference 34) was cloned into pUC8. Forty micrograms of this plasmid $\left(\mathrm{pB}^{\prime}\right)$ was digested with BamHI and then incubated for $40 \mathrm{~min}$ at $30^{\circ} \mathrm{C}$ with $0.5 \mathrm{U}$ of $\mathrm{Bal}$ 31 exonuclease. At 4-min intervals, 10- $\mu$ l samples were removed, and the reaction was stopped by adding $10 \mu l$ of $0.025 \mathrm{M}$ EDTA. The samples were pooled, phenol extracted, and precipitated with 2 volumes of ethanol. The ends of the DNA were repaired by incubating the DNA in $100 \mu \mathrm{l}$ for $30 \mathrm{~min}$ at $23^{\circ} \mathrm{C}$ with 4 $U$ of $E$. coli DNA polymerase (Klenow fragment). Phosphorylated BamHI linkers were added to the ends with T4 DNA ligase, the fragments were digested with $B a m \mathrm{HI}$ and $E c o$ RI, and truncated $\mathrm{pB}^{\prime}$ fragments with ca. 100- to 400-base-pair deletions were isolated from 
pro asp tyr ser tyr arg pro thr ile gly arg thr tyr val tyr asp asn lys tyr tyr lys asn leu gly ATG CCG GAT TAT TCA TAC CGT CCC ACC ATC GGG CGT ACC TAC GTG TAC GAC AAC AAG TAC TAC AAA AAT TTA GGT $+ 1 \longdiv { \text { Mepl } }$ pAc360 1 - PAc311

ala val ile lys asn ala lys arg lys lys his phe ala glu his glu ile glu glu ala thr leu asp pro leu GCC GTT ATC AAG AAC GCT AAG CGC AAG AAG CAC TTC GCC GAA CAT GAG ATC GAA GAG GCT ACC CTC GAC CCC CTA 76
Sau3A

Taql
Taql

\section{pAc101-}

asp asn tyr leu val ala glu asplpro phe leu gly pro gly lys asn gln lys leu thr leu phe lys glu ile GAC AAC TAC CTA GTG GCT GAG GAT CCT TTC CTG GGA CCC GGC AAG AAC CAA AAA CTC ACT CTC TTC AAG GAA ATC 151

arg asn val lys pro asp thr met lys leu val val gly trp lys gly lys glu phe tyr arg glu thr trp thr CGT AAT GTI AAA CCC GAC ACG ATG AAG CTT GTC GTT GGA TGG AAA GGA AAA GAG ITC TAC AGG GAA ACT TGG ACC 226

\section{HindIII}

FIG. 1. Nucleotide and amino sequence of the $5^{\prime}$ end of the polyhedrin gene. The DNA sequence of a segment of the polyhedrin gene and $5^{\prime}$ flanking region is presented as the sense $(+)$ strand and was determined using the dideoxy termination procedure (29). The sequence around the 5 ' end of the polyhedrin gene was determined from the following overlapping templates: the minus strand beginning at the HindIII or Bam HI sites in pAc101, the minus strand beginning at the synthetic BamHI sites in pAc311, pAc360, and pAc380, and the plus strand beginning at the BamHI or HindIII sites in pAc101 (Fig. 2). The location of the natural BamHI site in the transfer vector pAc101 and positions of the BamHI linkers in pAc311, pAc360, and pAc380 are indicated by arrows. The box at -58 marks the bases that code for the $5^{\prime}$ end of polyhedrin mRNA (34). The rectangles centered at -78 and -110 mark the nucleotides that resemble the canonical TATA and CAAT box sequences, respectively. The repeated CACAAACT sequences upstream from the CAAT box are underlined. The translational start signal for polyhedrin is assigned position +1 .

an agarose gel. The purified fragments were ligated to EcoRI- plus-BamHI-digested pUC8 and then used to transform JM83 cells. The sizes of the deletions in the resulting clones were estimated by restriction enzyme analysis and in some cases by DNA sequencing. The XhoI-to-BamHI fragment in pAC101 (located at 1,900 to 4,210 bases in EcoRI-I; 34) was removed and replaced with XhoI-to-BamHI linker fragments from several different $\mathrm{pB}^{\prime}$ mutant plasmids, using standard cloning procedures, to produce the modified transfer vectors pAc311, pAc360, and pAc380. These plasmids have single BamHI cloning sites in the polyhedrin gene at the locations indicated in Fig. 1.

DNA sequencing. AcNPV restriction fragments were cloned into M13mp8 or M13mp9 (19), and the singlestranded recombinant phage DNAs were purified and used as templates in the chain-termination sequencing method (29). The sequence was determined from overlapping DNA templates, and all autoradiographs were read independently at least twice. The sequence across all restriction enzyme sites in the polyhedrin gene was also determined.

\section{RESULTS}

Nucleotide sequence of the polyhedrin promoter and the construction of transfer vectors. The nucleotide sequence of the 5 ' end of the polyhedrin-coding region and 200 bases upstream from the start of translation is shown in Fig. 1. The site that specifies the $5^{\prime}$ end of polyhedrin mRNA has been mapped in a high-resolution S1 nuclease experiment to 220 bases in the $5^{\prime}$ direction from the single BamHI site that maps within the gene (Fig. 1;34). An ATG translational start signal (the A residue was assigned position +1 ) was located ca. 58 bases from the transcription start site, followed by an open reading frame for 244 amino acids. Proline is known to be the amino-terminal residue for AcNPV polyhedrin (J. Maruniak, Ph.D. thesis, University of Texas, Austin, 1980) and was the penultimate $\mathrm{N}$-terminal amino acid predicted from the DNA sequence (Fig. 1). The predicted sequence for AcNPV polyhedrin (Fig. 1) was 80 to $90 \%$ homologous with several other NPV polyhedrins (28). The complete sequence of the AcNPV polyhedrin gene will be presented in another report (Hooft van Iddekinge et al., in press). Located about 78 and 110 bases upstream from the translational start site were sequences that resembled, respectively, the canonical "TATA" and "CAAT" boxes found in similar positions in many eucaryotic structural genes (see reference 5 and references therein). Centered at -128 and -142 were the direct 


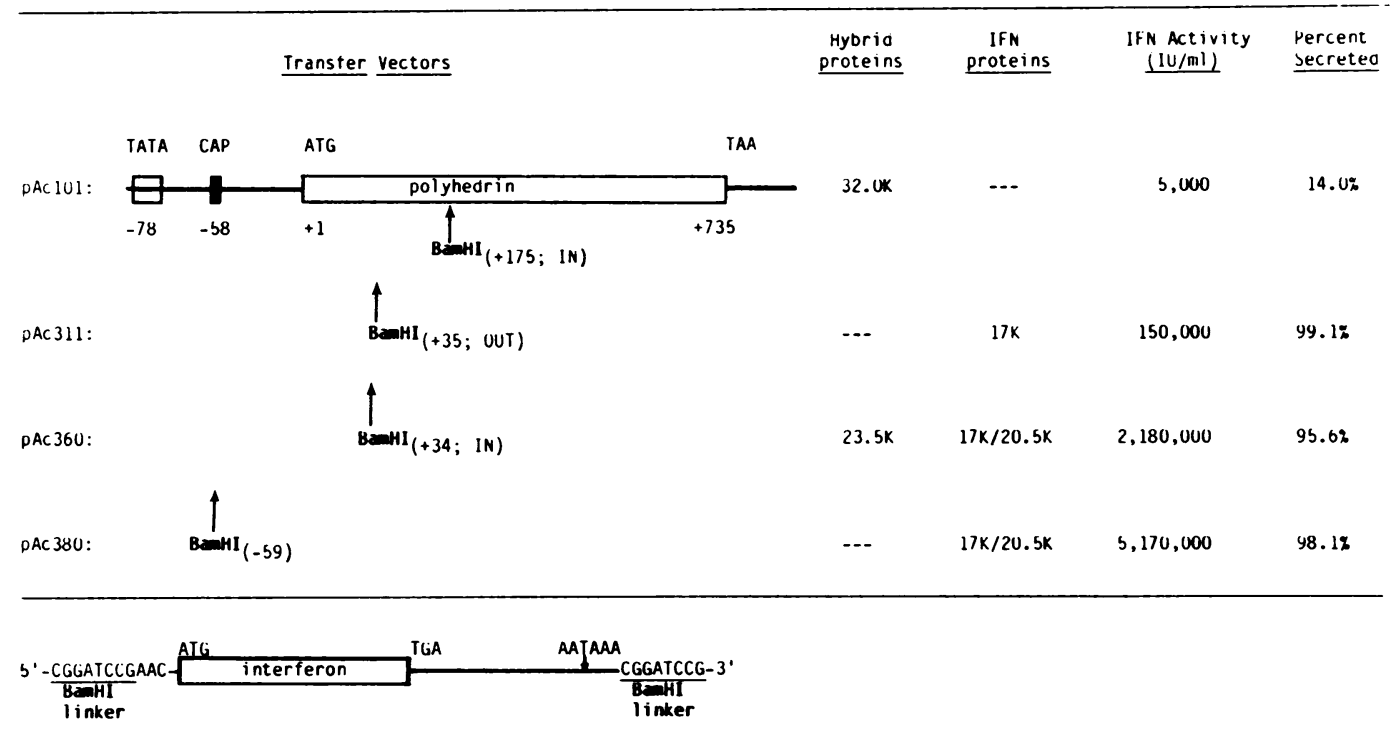

FIG. 2. Location of BamHI cloning sites in the transfer vectors pAc101, pAc311, pAc360, and pAc380 illustrated relative to the coding sequences (open rectangles), the putative cap site, and the TATA box sequences of the polyhedrin gene. The interferon fragment cloned into these BamHI sites is shown in the lower panel. When cloned into pAc101 and pAc360, the interferon coding sequences (open rectangle) are in the same reading frame as polyhedrin, and when cloned into pAc311 they are not. The polyhedrin-interferon hybrid proteins and $17 \mathrm{~K}$ non-glycosylated and $20.5 \mathrm{~K}$ glycosylated IFN- $\beta$ proteins produced by AcNPV expression vectors are indicated. Interferon was produced by AcNPV expression vectors, and the activity was measured as follows. $S$. frugiperda cells were infected at 20 PFU per cell with AcNPV or AcNPV expression vectors. For infection, $4 \times 10^{6} S$. frugiperda cells were seeded in $4 \mathrm{ml}$ of medium in a $25-\mathrm{cm}^{2}$ culture flask and then infected for $1 \mathrm{~h} \mathrm{at} 23^{\circ} \mathrm{C}$ with 1 $\mathrm{ml}$ of virus inoculum. Infected cells were washed, $4 \mathrm{ml}$ of fresh medium plus $10 \% \mathrm{FBS}$ were added, and the flasks were incubated at $27^{\circ} \mathrm{C}$ for $48 \mathrm{~h}$. The media were removed and centrifuged for $10 \mathrm{~min}$ at $3,000 \times \mathrm{g}$. The supernatant from each was centrifuged at $100,000 \times g$ for $30 \mathrm{~min}$ at $4^{\circ} \mathrm{C}$ and then stored at $-80^{\circ} \mathrm{C}$ until assayed. Infected cells were washed in phosphate-buffered saline, suspended at $2 \times 10^{6}$ cells per $\mathrm{ml}$, and then disrupted by mixing with an equal volume of $7 \mathrm{M}$ guanidine hydrochloride. Media and disrupted cells were assayed for interferon by the plaque-reduction assay and compared with an international interferon reference standard (18).

repeated nucleotides CACAAACT. These sequences may be analogous to the tandemly repeated promoter element ( -100 region) in, for example, the promoter region of rabbit beta globin (5). The AcNPV polyhedrin gene has a 58-base nontranslated leader sequence preceding the translational start codon, and, as suggested from S1 nuclease experiments of AcNPV polyhedrin mRNA (34) and R-loop mapping of another NPV polyhedrin mRNA (27), these were no intervening sequences.

The AcNPV genome has no known unique restriction sites into which genes can be conveniently introduced in a site-specific manner. To incorporate the gene for IFN- $\beta$ into the viral genome adjacent to the polyhedrin promoter, we first constructed chimeric plasmid vectors (transfer vectors). Each of these has both a cloning site near the polyhedrin promoter and flanking viral DNA linked to the $E$. coli plasmid pUC8. EcoRI fragment I was cloned into the EcoRI site in pUC8. There are three BamHI sites on this plasmid, one of which is located at position +175 in the polyhedrin gene (Fig. 1). The other two BamHI sites were removed, resulting in the transfer vector pAc101. From the nucleotide sequence of polyhedrin and interferon, it can be determined that the IFN- $\beta$ protein-coding sequences, when inserted into the unique Bam HI cloning site in pAc101, would be in the same translational reading frame as polyhedrin.

To investigate the importance of various polyhedrin gene sequences in the expression of IFN$\beta$, the transfer vector pAc101 was modified to have BamHI cloning sites at other positions near the $5^{\prime}$ end of the polyhedrin gene. Deletions were produced between the natural BamHI site at +175 and the polyhedrin promoter in pAc101, and a synthetic oligonucleotide containing a $B a m \mathrm{HI}$ recognition site was added at the points of deletion. The transfer vectors pAc311 and pAc360 have BamHI sites at +35 and +34 bases, respectively, downstream from the start site of polyhedrin translation (Fig. 1). The vector pAc380 has a BamHI cloning site at -59 , which 
is the putative cap site for polyhedrin mRNA (Fig. 1).

The nucleotide sequence for IFN- $\beta$ and the location of various transcription and translation signals are known $(4,10,23)$. A 767-base-pair HincII fragment from a genomic clone of human IFN- $\beta$ (pBR13; 11) (containing the entire protein coding sequences for IFN- $\beta$, three additional bases before the ATG translation start signal, and all of the nontranslated $3^{\prime}$ sequences including the signal for polyadenylation [23]) was cloned into the HincII site of pUC8. This fragment was joined to synthetic octanucleotide $B a m H I$ linkers and then cloned into the unique BamHI sites in pAc101, pAc311, pAc360, and pAc380 (Fig. 2). Plasmids were examined, using various restriction enzymes to obtain the transfer vectors in which IFN- $\beta$ was oriented in the same $5^{\prime}$ to $3^{\prime}$ direction as the polyhedrin gene, hereafter referred to as pAc101-IFN- $\beta$, pAc311IFN- $\beta$, pAc360-IFN- $\beta$, and pAc380-IFN- $\beta$. As an example, pAc380 and the location and orientation of the interferon fragment in this transfer vector are shown in Fig. 3 .

Construction of AcNPV expression vectors. Next, we transferred these hybrid polyhedrininterferon genes to the AcNPV genome. AcNPV DNA was mixed with each of the transfer vectors containing the hybrid genes, and $S$. frugiperda cells were transfected as described previously (30). Recombinant AcNPV with insertions of IFN- $\beta$ DNA was obtained from the resulting viral progeny by screening for plaques formed by viruses that did not produce occlusions $\left(\mathrm{O}^{-}\right.$ mutants). Of the viral plaques resulting from the virus produced in cells cotransfected with viral and plasmid DNAs, an average of $0.5 \%$ were formed from putative recombinant $\mathrm{O}^{-}$viruses. DNA restriction analysis demonstrated that each had the addition of IFN- $\beta$ DNA at the appropriate location in EcoRI fragment I and that no other changes in the viral DNAs were detected (data not shown). The recombinant viruses were, therefore, defective in the production of occlusions due to insertional inactivation of the polyhedrin gene. Referred to here as the viral expression vectors Ac101-IFN- $\beta$, Ac311IFN- $\beta$, Ac360-IFN- $\beta$, and Ac380-IFN- $\beta$ they resulted from recombination between AcNPV and the corresponding IFN- $\beta$ transfer vectors. The details of the relatively simple screening procedure used to select for AcNPV recombinants are described in a recent report (30).

Biologically active interferon is produced and secreted in cells infected with recombinant AcNPV. Cells infected with AcNPV-interferon expression vectors underwent morphological changes that are typical of $\mathrm{O}^{-}$viral infections (30). The entire infection process, including viral protein synthesis, viral assembly, and partial

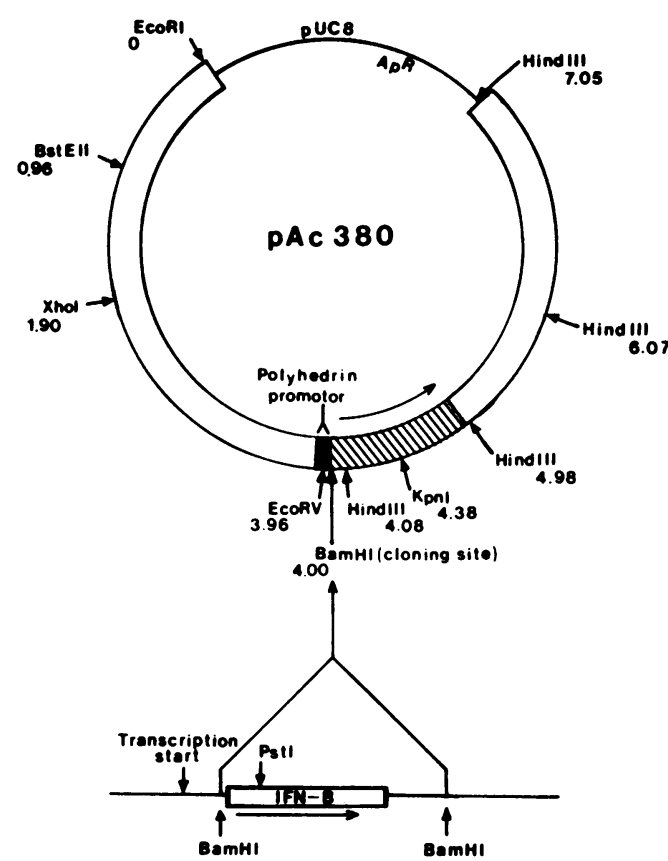

FIG. 3. AcNPV transfer vector $p A c 380$ and IFN- $\beta$. Arrows mark the approximate location of the polyhedrin mRNA coding sequences, and the positions of certain restriction sites are indicated in kilobase pairs. The BamHI cloning site at 4.00 is the position at which a deletion from +175 to -59 (Fig. 2) was introduced and replaced by a BamHI octanucleotide linker. BamHI linkers were added to a 767-base-pair HincII IFN- $\beta$ fragment and then cloned into the $B a m H I$ site in pAc380, producing the recombinant transfer vector pAc380-IFN- $\beta$. IFN- $\beta$ protein-coding sequences are indicated by the rectangle, and the long arrow marks the direction of transcription.

cell lysis, was complete by ca. $72 \mathrm{~h}$ p.i. There was a marked reduction in protein synthesis between 50 and $60 \mathrm{~h}$ p.i., and cell lysis was first detected at about $50 \mathrm{~h}$ p.i. The titer of recombinant AcNPV-infected cells reached a maximum of ca. $5 \times 10^{8} \mathrm{PFU} / \mathrm{ml}$ of medium, which is typical of AcNPV-infected cells. Thus, the insertion of interferon DNA into the polyhedrin gene had no major effect on the replication of these recombinant viruses.

To determine whether the AcNPV polyhedrin gene sequences could promote expression of IFN- $\beta$, the level of interferon activity was measured in $S$. frugiperda cells infected with each of the AcNPV expression vectors. Because interferon is normally secreted, media from infected cells were also tested for interferon activity. We used the virus plaque-reduction assay (18) in WISH cells challenged with vesicular stomatitis virus to determine interferon activity. If virus particles were removed by centrifugation, no interferon activity was measured in medium 


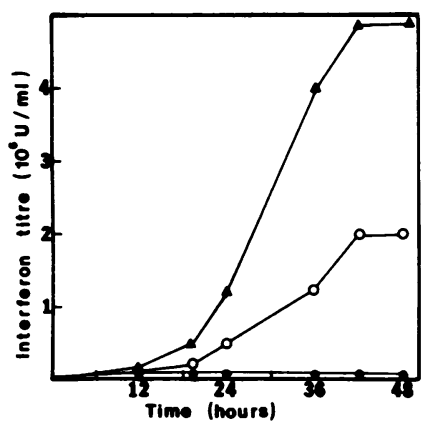

FIG. 4. Production of interferon activity in infected cells $S$. frugiperda cells were infected with AcNPV (O), Ac360-IFN- $\beta$ (O), or Ac380-IFN- $\beta$ ( $\Delta$ ). The interferon activity in the medium was measured at 0 , $12,20,24,36,42$, and 48 h p.i. as described for Fig. 2.

from wild-type AcNPV-infected cells. However, if AcNPV-containing media were used during interferon assays 1,000 to $3,000 \mathrm{U}$ of interferon per $\mathrm{ml}$ was produced, indicating that AcNPV virions apparently can induce the expression of endogenous interferon in WISH cells. Because many species of enveloped viruses are known to induce interferon production in human cells (39), these results were expected. To avoid this effect, all subsequent samples were centrifuged before testing.

Significant levels of interferon were detected by $48 \mathrm{~h}$ p.i. in cells infected with all of the expression vectors. Ac380-IFN- $\beta$, in which interferon was inserted about 19 bases downstream from the polyhedrin TATA box sequences, produced the highest levels (Fig. 2). Very high levels were also produced by Ac360IFN- $\beta$, in which interferon was located at +34 and in the same translational reading frame as polyhedrin. In contrast, very low levels of activity were produced in cells infected with Ac101IFN- $\beta$ (Fig. 2), in which interferon was in the same reading frame as polyhedrin but located much further downstream at +175 . Somewhat unexpected were the moderate levels of interferon activity produced by cells infected with Ac311-IFN- $\beta$ (Fig. 2), in which interferon was inserted at +35 and consequently not in the correct reading frame for polyhedrin. Described later is an examination of proteins produced in infected cells, which helps to explain these results.

The kinetics of interferon induction were examined in $S$. frugiperda cells infected with the expression vectors Ac360-IFN- $\beta$ and Ac380IFN- $\beta$. Samples of the medium were taken from 0 to $48 \mathrm{~h}$ p.i. and stored at $-80^{\circ} \mathrm{C}$ until assayed for interferon. The medium from Ac380-IFN- $\beta$ infected cells had about $10,000 \mathrm{IU}$ of interferon per $\mathrm{ml}$ at $12 \mathrm{~h}$ p.i., and this level increased to a maximum of nearly $5 \times 10^{6} \mathrm{IU} / \mathrm{ml}$ by $42 \mathrm{~h}$ p.i. (Fig. 4). A similar pattern of induction was observed in Ac360-IFN $\beta$-infected cells (Fig. 4). The synthesis of polyhedrin in AcNPV-infected cells is known to follow a similar temporal pattern of expression (see reference 33 and references therein).

Effects of IFN- $\beta$ on $S$. frugiperda cells. A potential limitation in using animal virus expression vectors for interferons (7) is that interferon itself can impose restraints upon the level of expression by interfering with the replication of the virus vector. The high levels of IFN- $\beta$ produced in $S$. frugiperda cells, using AcNPV as a vector, and the normal titer of virus that was produced suggested that interferon does not affect AcNPV replication. To examine whether human IFN- $\beta$ induced an antiviral state in $S$. frugiperda cells, the following experiment was conducted. Cells $\left(2 \times 10^{6}\right)$ were treated for $12 \mathrm{~h}$ with, per $\mathrm{ml}$, up to $5 \times 10^{6} \mathrm{IU}$ of interferon produced in Ac380-IFN- $\beta$-infected cells or $5 \times$ $10^{3}$ IU of an international standard of IFN- $\beta$, and the treated cells were infected with 100 PFU of AcNPV or Ac380-IFN- $\beta$. Exposure of the cells to human interferon had no measurable effect on the number of virus plaques that developed.

Protein synthesis in cells infected with AcNPV expression vectors. In the expression vector Ac380-IFN- $\beta$ the nucleotides between -59 and +175 were deleted and replaced by an IFN- $\beta$ gene fragment containing the interferon ATG translational start signal preceded by three bases and a synthetic BamHI linker (Fig. 2 and 3). This placed the interferon gene ATG protein start signal approximately the same number of bases downstream from the polyhedrin gene TATA box as the polyhedrin transcriptional start site, leaving little, if any, nontranslated leader at the $5^{\prime}$ end of the predicted mRNA for this hybrid gene. High levels of interferon activity were measured in the medium of Ac380-IFN- $\beta$-infected cells, indicating that the polyhedrin promoter efficiently directed the transcription of this gene. At 30 and $48 \mathrm{~h}$ p.i., two polypeptides of 17,000 (17K) and $20.5 \mathrm{~K}$ molecular weight were being made in Ac380-IFN- $\beta$ but not in AcNPV-infected cells (Fig. 5A and B). The sizes of nonglycosylated and glycosylated human IFN- $\beta$ proteins are reported to be comparable to the $17 \mathrm{~K}$ and $20.5 \mathrm{~K}$ polypeptides, respectively (3, $15)$. At $30 \mathrm{~h}$ p.i., the $17 \mathrm{~K}$ polypeptide was being made in Ac360-IFN- $\beta$-infected cells (Fig. 5A; see Fig. 7), and by $48 \mathrm{~h}$ p.i., both $17 \mathrm{~K}$ and $20.5 \mathrm{~K}$ polypeptides were detected (Fig. 5B). Only the $17 \mathrm{~K}$ polypeptide could be detected in Ac311IFN- $\beta$-infected cells at 30 and $48 \mathrm{~h}$ p.i. (data not shown). An abundantly produced $23.5 \mathrm{~K}$ protein was observed in Ac360-IFN- $\beta$-infected cells 

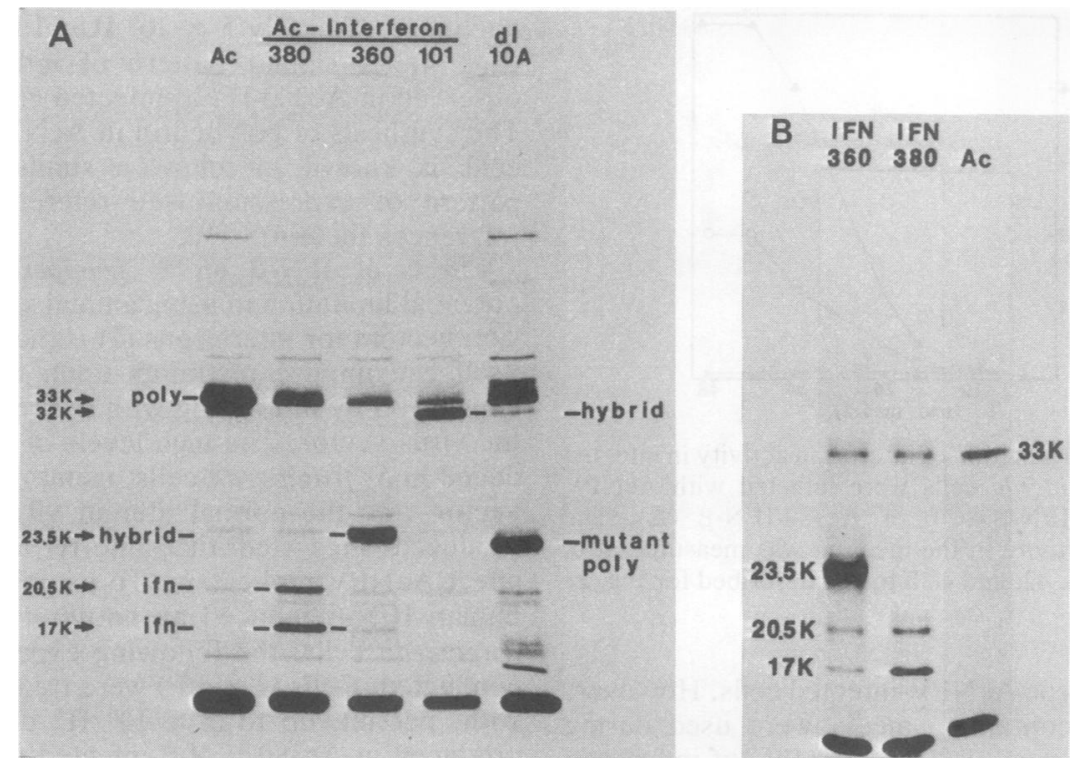

FIG. 5. Recombinant interferon produced in cells at (A) 30 or (B) 48 h p.i. (A) $S$. frugiperda cells were infected with AcNPV (Ac), Ac380-IFN- $\beta$, Ac360-IFN- $\beta$, Ac101-IFN- $\beta$, and dl10A (a deletion mutant of AcNPV that produces a truncated polyhedrin protein) and then labeled for 30 min with $\left[{ }^{3} \mathrm{H}\right]$ leucine at $30 \mathrm{~h}$ p.i. (B) $S$. frugiperda cells were infected with AcNPV (Ac), Ac380-IFN- $\beta$, and Ac360-IFN- $\beta$ and then labeled for 30 min with $\left[{ }^{3} \mathrm{H}\right]$ leucine at $48 \mathrm{~h}$ p.i. Total cell lysates were electrophoresed on a sodium dodecyl sulfate-12\% polyacrylamide gel; the gel was impregnated with $\mathrm{En}^{3} \mathrm{Hance}$ (New England Nuclear Corp., Boston, Mass.) and exposed to X-ray film for 2 days at $-80^{\circ} \mathrm{C}$. The molecular weights $\left(\times 10^{3}\right)$ of certain polypeptides are indicated.

(Fig. 5A and B) and has the size expected for a hybrid protein consisting of the entire interferon protein, including the 21 amino acid signal peptide plus an additional 14 amino acids derived from the first 10 codons of the polyhedrin gene and the BamHI linker sequences (Fig. 1 and 2).

In the expression vector Ac101-IFN- $\beta$, the interferon fragment was inserted into the natural AcNPV BamHI site at +175 in the same translational reading frame as polyhedrin. A putative hybrid $32 \mathrm{~K}$ polypeptide was made in cells infected with this expression vector (Fig. 5). The size of the protein was as predicted from the DNA sequence.

Immunological identification of recombinant products. The $17 \mathrm{~K}$ and $20.5 \mathrm{~K}$ proteins being made in Ac380-IFN- $\beta$ - and, to a lesser extent, Ac360-IFN- $\beta$-infected cells reacted with human IFN- $\beta$ monoclonal antibody (Fig. $6 \mathrm{C}$ ). The autoradiogram shown in Fig. 6 is a 6-h exposure, and the reaction of IFN- $\beta$ antibody to the $20.5 \mathrm{~K}$ protein was more obvious with longer exposure times. The reduced reaction of this antibody to the $20.5 \mathrm{~K}$ protein as compared with that to the $17 \mathrm{~K}$ protein was in part due to the fact that $17 \mathrm{~K}$ accumulates to higher levels in cells than does 20.5K (data not shown). In addition, the antibody may be reacting to an epitope on the $17 \mathrm{~K}$ polypeptide that is partially masked by, for example, glycosylation of the $20.5 \mathrm{~K}$ polypep- tide. The putative hybrid $23.5 \mathrm{~K}$ and $32 \mathrm{~K}$ proteins also reacted with IFN- $\beta$ antibody (Fig. $6 \mathrm{C})$. Polyclonal antibody to polyhedrin recognized the 10 amino acids of the $23.5 \mathrm{~K}$ protein and the 57 amino acids of the $32 \mathrm{~K}$ protein that would be predicted from the DNA sequence to be present at the $\mathrm{N}$-terminal ends of the hybrid proteins (Fig. 6B).

Glycosylation of IFN- $\beta$ in infected cells. Tunicamycin is a specific inhibitor of glycosylation which prevents the assembly of glycoproteins (38). The inhibitor has been used to produce nonglycosylated IFN- $\beta$ (42) and is effective in AcNPV-infected $S$. frugiperda cells (36). In the presence of tunicamycin, a $64 \mathrm{~K}$ AcNPV glycoprotein (6) was missing and a new protein of $58 \mathrm{~K}$ was present (Fig. 7), indicating that the concentration of inhibitor used in this experiment $(5 \mu \mathrm{g} /$ $\mathrm{ml}$ ) was sufficient to block glycosylation of this protein. Tunicamycin had little effect on the synthesis of the $17 \mathrm{~K}$ IFN- $\beta$ or the $23 \mathrm{~K}$ and $32 \mathrm{~K}$ hybrid proteins in Ac360-IFN- $\beta$ - and Ac101IFN- $\beta$-infected cells (Fig. 7). However, no 20.5K IFN- $\beta$ was produced in the presence of tunicamycin in cells infected with Ac360-IFN- $\beta$ (Fig. 7) or Ac380-IFN- $\beta$ (data not shown).

To further demonstrate that $20.5 \mathrm{~K}$ IFN- $\beta$ was gylcosylated, Ac380-IFN- $\beta$-infected cells were labeled late in infection with $\left[{ }^{3} \mathrm{H}\right]$ mannose. The $20.5 \mathrm{~K}$ IFN- $\beta$ and three additional proteins were 


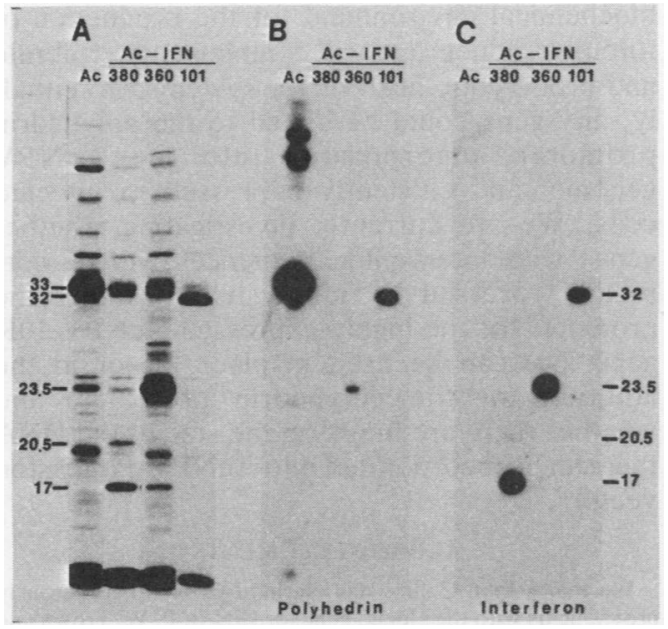

FIG. 6. Immunological identification of interferon and polyhedrin-interferon hybrid proteins. At $40 \mathrm{~h}$ p.i., total-cell lysates from AcNPV (Ac)-, Ac380-IFN- $\beta-$, Ac360-IFN- $\beta$-, and Ac101-IFN- $\beta$ - infected cells were electrophoresed on a sodium dodecyl sulfate-12\% polyacrylamide gel, transferred by diffusion to two nitrocellulose filters, and incubated with either polyhedrin antiserum or IFN- $\beta$ monoclonal antibody as described previously (32). Specifically bound antibody was detected with ${ }^{125}$ I-labeled protein $A$, and the filters were exposed to X-ray film at $-80^{\circ} \mathrm{C}$ for $6 \mathrm{~h}$ with the aid of an intensifying screen. (A) Autoradiogram of infected cells labeled with $\left[{ }^{3} \mathrm{H}\right]$ leucine at $40 \mathrm{~h}$ p.i. as described for Fig. 5. The molecular weights $\left(\times 10^{3}\right)$ of certain proteins are marked.

the major mannose-containing glycoproteins labeled in Ac380-IFN-B-infected cells (Fig. 8). A summary of the $17 \mathrm{~K}$ non-glycosylated and $20.5 \mathrm{~K}$ glycosylated IFN- $\beta$ and the polyhedrinIFN- $\beta$ hybrid proteins produced by the various expression vectors is given in Fig. 2.

\section{DISCUSSION}

We have demonstrated that exceptionally high levels of interferon were produced in cells infected with a recombinant AcNPV expression vector in which the gene for IFN- $\beta$ was placed under the transcriptional control of the polyhedrin promoter. Based on the specific activity of purified interferon (14), we estimate that ca. 10 $\mu \mathrm{g}$ of interferon was secreted by $10^{6} S$. frugiperda cells infected with Ac380-IFN- $\beta$. In Ac380-IFN- $\beta$, the coding sequences for interferon were linked to the polyhedrin promoter at -59 (ca. 19 bases downstream from the canonical TATA sequences), suggesting that (i) polyhedrin gene sequences upstream from -59 were primarily responsible for the regulation of transcription and (ii) the 58-base nontranslated 5'- leader sequence of polyhedrin was not absolutely required for efficient expression.

Cleavage of the signal peptide of pre-IFN- $\beta$ is thought to be essential for producing biologically active, mature IFN- $\beta(3,37)$. Therefore, the polyhedrin-IFN- $\beta$ hybrid proteins produced by the vectors Ac360-IFN- $\beta$ and Ac101-IFN- $\beta$, which almost certainly still have the pre-IFN- $\beta$ signal peptide as well as additional polyhedrin sequences, were most likely not biologically active. Much of the mature IFN- $\beta$ produced by Ac360-IFN- $\beta$ was probably a result of the removal of the signal peptide from some of the $23.5 \mathrm{~K}$ hybrid gene product, in spite of the fact that the 21-amino acid signal sequence was an additional 14 amino acids from the $\mathrm{N}$-terminal end of the protein. Sequence analysis of IFN- $\beta$ and the hybrid proteins will be needed to confirm these speculations. Mature IFN- $\beta$ may have also been produced by Ac360-IFN- $\beta$ by another mechanism. It can be predicted from the scanning model for eucaryotic translation initiation (16) that the polyhedrin protein start sequence AUAAUGC is less favorable for initia-

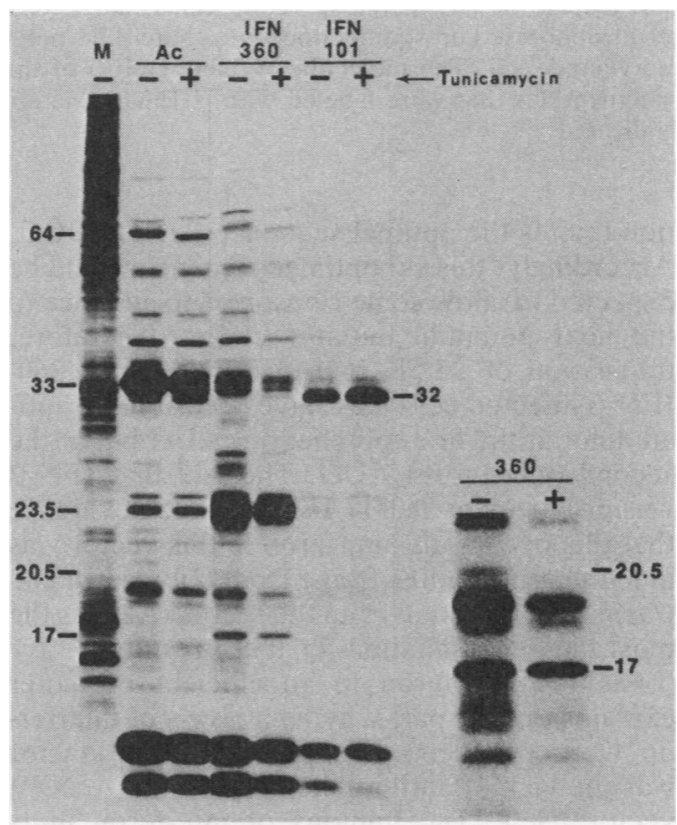

FIG. 7. Effects of tunicamycin on the synthesis of interferon At 30 h p.i. mock (M)-, AcNPV (Ac)-, Ac360-IFN- $\beta$-, and Ac101-IFN- $\beta$ - infected cells were labeled with $\left[{ }^{3} \mathrm{H}\right]$ leucine for $30 \mathrm{~min}$ in the presence or absence of $5 \mu \mathrm{g}$ of tunicamycin per $\mathrm{ml}$. Infected cells were pretreated for $10 \mathrm{~h}$ in medium plus $5 \mu \mathrm{g}$ of tunicamycin per $\mathrm{ml}$ before being labeled in the presence of the inhibitor. A longer exposure of Ac360IFN- $\beta$-labeled proteins is shown in the right panel. The molecular weights $\left(\times 10^{3}\right)$ of certain proteins are marked. 


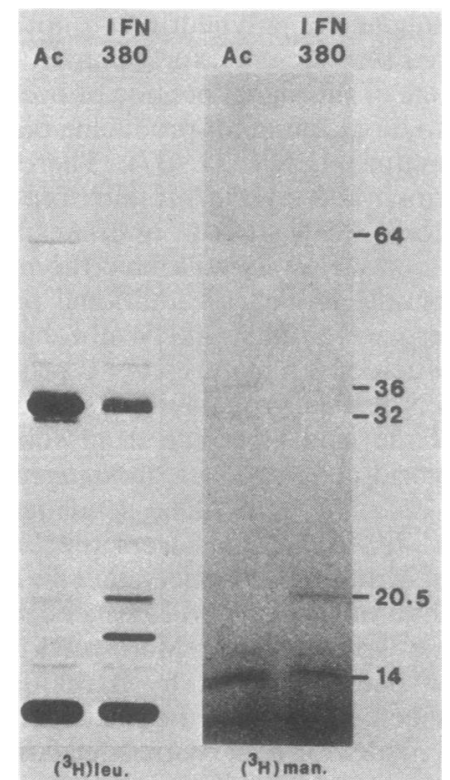

FIG. 8. Incorporation of $\left[{ }^{3} \mathrm{H}\right]$ mannose into recombinant interferon. AcNPV (Ac)- and Ac380-IFN- $\beta$ infected cells were labeled for $1 \mathrm{~h}$ at $40 \mathrm{~h}$ p.i. with $\left[{ }^{3} \mathrm{H}\right]$ leucine or $\left[{ }^{3} \mathrm{H}\right]$ mannose. Total cell lysates were electrophoresed on sodium dodecyl sulfate-12\% polyacrylamide gel. The molecular weights $\left(\times 10^{3}\right)$ of the polypeptides that were labeled with $\left[{ }^{3} \mathrm{H}\right]$ mannose are indicated.

tion than is the optimal sequence PuNNAUGG. Accordingly, this suboptimal sequence would be expected to allow some ribosomes to advance to the next potential initiator codon. Therefore, translation of $23.5 \mathrm{~K}$ hybrid mRNA in Ac360IFN- $\beta$ infected cells may have occasionally initiated not at the first (polyhedrin) AUG but at the second (interferon) AUG. The fact that IFN- $\beta$ was produced by Ac311-IFN- $\beta$ is good evidence that this occurs, as interferon in this vector was in a different reading frame from polyhedrin and translation initiation from the second AUG is the most likely explanation for these results.

Linking interferon to an efficient promoter explains only in part why high levels of interferon were produced. Another important factor was the lack of antiviral activity on the AcNPV vector itself. The millions of interferon units produced per milliliter in our system had no measurable effect on virus yields, whereas only $100 \mathrm{U}$ of interferon per $\mathrm{ml}$ reduces the yield of simian virus 40 by up to $80 \%$ (7), limiting the use of this and similarly affected vertebrate animal viruses as vectors for interferon.

AcNPV and other baculoviruses should prove to be important vectors for the production of cloned gene products in insect cells or organisms. The invertebrate cell will provide a unique biochemical environment for the production of foreign products and will complement vertebrate and procaryotic host-vector systems. Potentially, any gene could be linked to the polyhedrin promoter, incorporated into the AcNPV genome, and efficiently expressed in infected cells. We are currently investigating whether genes with intervening sequences will be correctly processed in this system, whether the promoter for the highly expressed AcNPV $10 \mathrm{~K}$ gene (34) can be used in place of, or in the addition to, the polyhedrin promoter, and whether there are limits on the size of the DNA that can be incorporated into AcNPV expression vectors.

\section{ACKNOWLEDGMENTS}

We thank John Collins and Gerhard Gross for generously providing us with the cloned gene for IFN- $\beta, P$. W. Trown and Hoffmann-LaRoche Inc. for providing monoclonal antibody to IFN- $\beta$, Dennis Brown for the vesicular stomatitis virus, Ann Sorensen and Carol Rix for reviewing the manuscript. Bart Hooft van Iddekinge for assistance in DNA sequencing, and Carol Rix for technical assistance in interferon assays.

This work was supported in part by Public Health Service grant AI 14755 from the National Institutes of Health and by Texas Agricultural Experiment Station project TEXO 6316.

\section{ADDENDUM IN PROOF}

After this report was submitted for review a study by Remaut et al. (E. Remaut, P. Stanssens, and W. Fiers, Nucleic Acids Res. 14:4677-4688, 1983) was published which described the synthesis of mature IFN- $\beta$ under the transcriptional control of a phage lambda promoter in $E$. coli cells at a level similar to that which was reported here.

\section{LITERATURE CITED}

1. Adang, M. J., and L. K. Miller. 1982. Molecular cloning of DNA complementary to RNA of the baculovirus A utographa californica nuclear polyhedrosis virus: location and gene products of RNA transcripts found late in infection. J. Virol. 44:782-793.

2. Canaani, D., and P. Berg. 1982. Regulated expression of human interferon $\beta_{1}$ gene after transduction into cultured mouse and rabbit cells. Proc. Natl. Acad. Sci. U.S.A. 79:5166-5170.

3. Content, J., L. De Wit, R. Derynck, E. De Clercq, and W. Fiers. 1982. In vitro cotranslational procession of human pre-interferon $\beta_{1}$ enhances its biological activity. Virology 122:466-470.

4. Derynck, R., J. E. Content, G. De Clerca, J. Volckaert, R. Tavernier, R. Devos, and W. Fiers. 1980. Isolation and structure of a human fibroblast interferon gene. Nature (London) 285:542-547.

5. Dierks, P., A. van Ooyen, M. D. Cochran, C. Dobkin, J. Reiser, and C. Weissman. 1983. Three regions upstream from the cap site are required for efficient and accurate transcription of the rabbit $\beta$-globin gene in mouse 3T6 cells. Cell 32:695-706.

6. Dobos, P., and M. A. Cochran. 1980. Proteins in cells infected by Autographa californica nuclear polyhedrosis virus (Ac-NPV): the effect of cytosine arabinoside. Virology 103:446-464.

7. Gheysen, D., and W. Fiers. 1982. Expression and excretion of human fibroblast $\beta_{1}$ interferon in monkey cells after transfection with a recombinant SV40 plasmid vector. J. Mol. Appl. Genet. 1:385-394.

8. Goeddel, D. V., H. M. Shepard, E. Yelverton, D. Leung, R. Crea, A. Sloma, and S. Pestka. 1980. Synthesis of 
human fibroblast interferon by $E$. coli. Nucleic Acids Res. 8:4057-4074.

9. Grace, T. D. C. 1962. Establishment of four strains of cells from insect tissue grown in vitro. Nature (London) 195:788-789.

10. Gross, G., U. Mayr, W. Bruns, F. Grosveld, H.-H. M. Dahl, and J. Collins. 1981. The structure of a thirty-six kilobase region of the human chromosome including the fibroblast interferon gene IFN- $\beta$. Nucleic Acids Res. 9:2495-2507.

11. Hauser, H., G. Gross, W. Bruns, H.-K. Hochkeppel, U. Mayr, and J. Collins. 1982. Inducibility of human $\beta$ interferon gene in mouse L-cell clones. Nature (London) 297:650-654.

12. Hink, W. F. 1970. Established insect cell line from the cabbage looper, Trichoplusia ni. Nature (London) 226:466-467.

13. Kelly, D. C. 1982. Baculovirus replication. J. Gen. Virol. 63:1-13.

14. Knight, E., Jr. 1976. Interferon: purification and initial characterization from diploid cells. Proc. Natl. Acad. Sci. U.S.A. 73:520-523.

15. Knight, E., Jr., and D. Fahey. 1982. Human interferonbeta: effects of deglycosylation. J. Interferon Res. 2:421429.

16. Kozak, M. 1983. Comparison of initiation of protein synthesis in procaryotes, eucaryotes, and organelles. $\mathrm{Mi}$ crobiol. Rev. 47:1-45.

17. Laemmli, U. K. 1970. Cleavage of structural proteins during the assembly of the head of bacteriophage T4. Nature (London) 227:680-685.

18. Langford, M. P., D. A. Weigent, F. J. Stanton, and S. Baron. 1981. Virus plaque-reduction assay for interferon: microplaque and regular macroplaque reduction assays. Methods Enzymol. 78:339-346.

19. Messing, J., and J. Vieira. 1982. A new pair of M13 vectors for selecting either DNA strand of double-digest restriction fragments. Gene 19:269-276.

20. Miller, L. K., A. J. Lingg, and L. A. Bulla, Jr. 1983. Bacterial, viral, and fungal insecticides. Science 219:715721.

21. Mitrani-Rosenbaum, S., L. Maroteaux, Y. Mory, M. Revel, and P. M. Howley. 1983. Inducible expression of the human interferon $\beta_{1}$ gene linked to a bovine papilloma virus DNA vector and maintained extrachromosomally in mouse cells. Mol. Cell. Biol. 3:233-240.

22. Mory, Y., Y. Chernajovsky, S. Feinstein, L. Chen, U. Nir, J. Weissenbach, Y. Malpiece, P. Tiollais, D. Marks, M. Ladner, C. Colby, and M. Revel. 1981. Synthesis of human interferon $\beta_{1}$ in Escherichia coli infected by a lambda phage recombinant containing a human genomic fragment. Eur. J. Biochem. 120:197-202.

23. Ohno, S., and T. Taniguchi. 1981. Structure of a chromosomal gene for human interferon $\beta$. Proc. Natl. Acad. Sci. U.S.A. 78:5305-5309.

24. Ohno, S., and T. Taniguchi. 1982. Inducer-responsive expression of the cloned human interferon $\beta_{1}$ gene introduced into cultured mouse cells. Nucleic Acids Res. 10:967-977.

25. Reyes, G. R., E. R. Gavis, A. Buchan, N. B. K. Raj, G. S. Hayward, and P. M. Pitha. 1982. Expression of human $\beta$ interferon cDNA under the control of a thymidine kinase promoter from herpes simplex virus. Nature (London) 297:598-601.

26. Rohel, D. Z., M. A. Cochran, and P. Faulkner. 1983.
Characterization of late mRNAs of Autographa californica nuclear polyhedrosis virus. Virology 124:357-365.

27. Rohrmann, G. F., D. J. Leisy, K.-C. Chow, G. D. Pearson, and G. S. Beaudreau. 1982. Identification, cloning, and Rloop mapping of the polyhedrin gene from the multicapsid nuclear polyhedrosis virus of Orgyia pseudotsugata. Virology 121:51-60.

28. Rohrmann, G. F., M. N. Pearson, T. J. Bailey, R. R. Becker, and G. S. Beaudreau. 1981. N-terminal polyhedrin sequences and occluded Baculovirus evolution. J. Mol. Evol. 17:329-333.

29. Sanger, F., S. Nicklen, and A. R. Coulsen. 1977. DNA sequencing with chain-termination inhibitors. Proc. Natl. Acad. Sci. U.S.A. 74:5463-5467.

30. Smith, G. E., M. J. Fraser, M. D. Summers. 1983. Molecular engineering of the Autographa californica nuclear polyhedrosis virus genome: deletion mutations within the polyhedrin gene. J. Virol. 46:584-593.

31. Smith, G. E., and M. D. Summers. 1978. Analysis of baculovirus genomes with restriction endonucleases. $\mathrm{Vi}$ rology 89:517-527.

32. Smith, G. E., and M. D. Summers. 1981. Application of a novel radioimmunoassay to identify baculovirus structural proteins that share interspecies antigenic determinants. J. Virol. 39:125-137.

33. Smith, G. E., J. M. Vlak, and M. D. Summers. 1982. In vitro translation of Autographa californica nuclear polyhedrosis virus early and late mRNAs. J. Virol. 44:199 208.

34. Smith, G. E., J. M. Vlak, and M. D. Summers. 1983 Physical analysis of Autographa californica nuclear polyhedrosis virus transcripts for polyhedrin and 10,000-molecular-weight protein. J. Virol. 45:215-225.

35. Stewart, W. E., II. 1979. The interferon system. Springer, Vienna, Austria.

36. Stiles, B., H. A. Wood, and P. R. Hughes. 1983. Effect of tunicamycin on the infectivity of Autographa californica nuclear polyhedrosis virus. J. Invertebr. Pathol. 41:405408.

37. Taniguchi, T., L. Guarente, T. M. Roberts, D. Kimelman, J. Douhan III, and M. Ptashne. 1980. Expression of the (human) fibroblast interferon gene in $E$. coli. Proc. Natl. Acad. Sci. U.S.A. 77:5230-5233.

38. Tkacz, J. S., and J. O. Lampen. 1975. Tunicamycin inhibition of polyisoprenyl $\mathrm{N}$-acetylglucosaminyl pyrophosphate formation in calf-liver microsomes. Biochem. Biophys. Res. Commun. 65:489-257.

39. Torrence, P. F., and E. De Clercq. 1981. Interferon inducers: general survey and classification. Methods Enzymol. 78:291-299.

40. van der Beek, C. P., J. D. Saajer-Riep, and J. M. Vlak. 1980. On the origin of the polyhedral protein of Autographa californica nuclear polyhedrosis virus. Virology 100:326-333.

41. Vieira, J., and Messing, J. 1982. The pUC plasmids, a M13mp7 derived system for insertion mutagenesis and sequencing with synthetic universal primers. Gene 19:259-268.

42. Yip, Y. K., and J. Vilcek. 1981. Production of human fibroblast interferon in the presence of the glycosylation inhibitor tunicamycin. Methods Enzymol. 78:212-219.

43. Zinn, K., P. Mellon, M. Ptashne, and T. Maniatis. 1982 Regulated expression of an extrachromososmal human $\beta$ interferon gene in mouse cells. Proc. Natl. Acad. Sci. U.S.A. 79:4897-4901. 